will get "the exact curve of the thing" (Speculations [London: Routledge, 1958] 137). When Pound and Hulme demand a classical style of poetry that sheds all the vagueness of language in favor of a sculptural, precise Truth, they are invoking a linguistic ideal of visual representation-an austere formalism-with roots in the nineteenth century and earlier.

Yet if Ruskin's Modern Painters presages the modernist desire for objective form, it also unwittingly reveals, in grand style, the potential for language to convey an unmediated record of sensation itself. The famous set pieces from Modern Painters, with extravagant sentences that pile sense upon sense, might be pointed to as early progenitors of the modernist techniques of stream of consciousness. Ruskin assaults the dull conventions of old-master landscapists by using a language that defies all formula, even deforming language to pierce through to a psychological truth of perception. Many of these famous passages describe not Turner's paintings, but Ruskin's own experiences in nature as he toured the popular mountainsides and landscapes of Europe. Turner's images are superior because they most closely approximate actual human perceptions of nature, as sensed by Ruskin himself. Even while Ruskin works to generalize and classify the unchanging forms of nature, Modern Painters is dominated by the author's subjective "I." His language performs a psychological autobiography of his personal history in nature. Modernist prose stylists also manipulated language to imitate the unpredictable streams of thoughts and sensations; in this, they remade Ruskin's linguistic process into a more deliberate and conscious artistic action.

So Modern Painters anticipates modernism in its allegiance to two contradictory visions of art's relation to the world, one in which art produces an idealized record of human conscious- ness, and another in which it offers an avenue to objective truths beyond the distorting influence of personal sentiment.

I disagree with Ra'ad that Ruskin was demolishing "traditional aesthetics" to pave the way for an unheralded modernism. This account rehashes the tired clichés of rupture and newness that so often characterize genealogies of modernism. A more complex account, as my comments suggest here, will look to see not only what has changed but also what has persisted.

Rachel Teukolsky

Pennsylvania State University, University Park

\section{Challenges Facing Older Scholars}

\section{To THE Editor:}

The publication in our journal of advertisements for research fellowships led me, an eighty-three-year-old, to investigate some of them further on the Internet. I am still a very active scholar and still publishing, but my pension is small, and research (including flights and accommodation) is expensive. Imagine my dismay when I found that several of the YaleBeinecke fellowships are age-restricted in various ways.

It is hard enough for a retired scholar to jump through all the hoops now required by federal, state, and private grant-awarding institutions, let alone be ruled out of the competition altogether. Shame on them. It doesn't benefit the university, our membership association, or the teaching profession to eliminate genuine contributions by academics of any age. It would be interesting to know how many other scholars share my dismay.

Eric H. Robinson Falls Church, VA 